\title{
THE SACRED IMAGE. FROM TRADITIONAL VIEW TO POSTMODERNITY
}

\author{
Alexandru-Corneliu ARION*
}

\begin{abstract}
Motto: "The fate of an epoch that has eaten of the tree of knowledge is that it must ....recognize that general views of life and the universe can never be the products of increasing empirical knowledge, and that the highest ideals, which move us most forcefully, are always formed only in the struggle with other ideal which are just as sacred to others as ours are to us" (Max Weber)
\end{abstract}

\begin{abstract}
The present paper deals with a very important factor which determines a culture or a civilization: the image(s). One way to categorize religious traditions is whether or not they accept or advocate the use of two- and/or three-dimensional objects to symbolize or embody the divine. Some traditions, such as Hinduism, Buddhism, and Orthodox and Catholic Christianity, see the use of such images as central to their theologies and rituals. In these traditions images can serve three functions. They can be understood to be representations or likenesses of deities, symbols of deities, or the deities themselves. Other traditions, such as some schools of Islam, Judaism, and Reformed Protestant Christianity, are iconoclastic or otherwise oppose the use of images. But for the last few decades the sacredness of the image has passed through many avatars due to the new conditions of living or, more precisely, to the new paradigms of thinking. Among those imposed by the postmodernity are: the denial of metaphysics and radicalization of hermeneutics, as science of interpretation; deconstructivism, viz. all that was built by man (or God) can be deconstructed; there is no objective truth, because what we call objective truth is merely fiction; there is no absolutes, everything is relative, in all levels, from knowledge to moral and culture. Contemporary civilization, regarded as marking the end of "Gutenberg Galaxy" and so of the conceptual abstraction, enjoys the ubiquity of images of the
\end{abstract}

PhD, Faculty of Theology and Sciences of Education, Chair of History and Philosophy of Religion, 'Valahia' University of Târgovişte, Romania. 
universe, manufactured, distributed and reproduced through a variety of means, and covering a very broad spectrum of human activities. Rehabilitation of images power carried by denouncing the exorbitant authority of reason gave birth to fear of the artifact, of the hyper-reality or simulacrum. The image has slipped from ambition to have access to a reality that must not in so much represent it as to manifest it -, to insert it effectively in the visible world -, to the ambition to seize the reality by promoting a system of signs that functions virtually empty and that refers to nothing else but to itself, that is to a logic of nonsense.

Keywords: image, postmodernity, deconstructivism, objective truth.

\section{Introduction}

The images are omnipresent in the life of the spirit: they support perception, accompany our affections and penetrate our conceptions. The image is often considered wandering or errant, uncontrollable, disturbing, responsible for our errors and mistakes. This is because the image plays an irreplaceable role as an adjuvant or intermediary when it is subservient to the constraints of external impressions that condition our adaptation to the real, or is subject to the more abstract representations that allow us to use judgment, reasoning and reflection for pragmatic or speculative purposes ${ }^{1}$.

The term image comes from Latin imago, which denotes an imitation, a copy, a likeness, among several other meanings. In its earliest English usage, image referred to a fabricated imitation or representation of the external form of an object and applied particularly to sculpted figures of saints and divinities that were treated as objects of religious devotion. As an ideal type, the veneration of images may be taken as venerative acts directed toward physical icons that represent divinities or other sacred beings anthropomorphically. However, divine beings are notoriously multiform, and they are heterogeneous in making themselves present in a great variety of objects. Not just sculpted images but paintings and drawings, abstract forms, diagrams, stones, trees, and other physical

${ }^{1}$ Jean-Jacques WunEnBurger, Filozofia imaginii (The philosophy of the image), edited and Afterword by Sorin Alexandrescu, Romanian transl. by Muguraş Constantinescu, Iaşi, Polirom, 2004, p. 245. 
objects as well as mentally projected visualizations may serve as objects of veneration. More than simply signifying those beings, icons are often considered and honored as living beings, animated by the actual presence of the beings they represent ${ }^{2}$.

In the present paper we try to underscore a very important factor which determines a culture or a civilization: the (sacred) image(s). And this pivotal aspect of almost any civilization will be surveyed in the classical or traditional period of Christianity (and not only) up to the postmodernism of today.

\section{Images: Icons or Idols in the History of Religion}

A serious token which looks for understanding the religious traditions is whether or not they accept or make use of two- or threedimensional objects to symbolize or even embody the divine. There are Eastern religions, such as Hinduism, Buddhism, and Western traditions like Orthodox and Catholic Christianity that see the use of such images as midmost to their theologies and cults. In these traditions images can serve three functions. They can be understood to be representations or likenesses of deities, symbols of deities, or the deities themselves. But there are also traditions, such as main part of Islam, Judaism, and Reformed Protestant Christianity, opposed to the former approach and hence iconoclastic or adversary to the use of images ${ }^{3}$.

Scholars of art and religion generally prefer the use of the terms image and icon to idol, as they argue that the former terms are more objective and less judgmental. For most English or Romanian speakers the word idol is inevitably associated with idolatry or heathen idolatry, and so brings with it theological implications of the biblical and Protestant critiques of images.

Anthropologists, on the other hand, tend to be comfortable using the word idol and argue that it more accurately reflects the theological

2 Richard H. DAvis, "Images: veneration of images", in Lindsay JONES (ed.), Encyclopedia of Religion, Vol. 7: Iconography - Justin Martyr, Macmillan Reference USA, Thomson Gale, 2005, p. 4379-4380.

${ }^{3}$ John E. CORT, "Images: images, icons, and idols", in Encyclopedia of Religion, p. 4388. Still others, such as Lutheran Christianity and the Advaita Vedānta school of Hinduism, are ambivalent or indifferent to the use of images. 
and ritual understanding of Hindus, Buddhists, and Jains who themselves use idol in English. Furthermore, they say not to use the term is to disrespect those who in good faith do use it, by implying that their use of the term betrays an ignorance of the negative connotations of idolatry in Abrahamic theologies. Still other scholars of religion prefer to use idol on the grounds that image is too neutral a term. These scholars argue that image does not convey adequately the depth of feelings aroused by idols in both devotees and critics. Despite the good arguments in favor of using idol, this paper will use image.

\subsection{Types of images}

The difference between an image and an icon is in many cases an arbitrary one. In Christian usage, icon refers only to two-dimensional representations of Jesus Christ, the Virgin Mary, or a saint, and so for many English-speakers icon calls to mind a two-dimensional object. Many scholars follow this theological distinction and use the term icon to refer only to two-dimensional objects. Most historians of art and religion use image to refer to any of many material objects, both of two and three dimensions, and restrict the use of icon to an image that is ritually consecrated and/or in some way participates in the divine substance of that which it represents.

Three-dimensional images can be of stone, metal, wood, lacquer, or clay. An image can be a figurative likeness (iconic) or abstract (aniconic). In India, the original image at a shrine is oftentimes an aniconic natural feature, understood to be a manifestation of divine power. As its popularity grows, patrons build increasingly elaborate shrines around the image and replace the original natural image with a humanly crafted iconic one.

Two-dimensional images generally are iconic. They can be on paper, wood, or cloth, and the figure can be painted, woven, or embroidered.

Some traditions, such as Buddhism and Catholic Christianity, employ both two- and three-dimensional images. Others, such as Hinduism and Jainism, exhibit a preference for three-dimensional images over two-dimensional ones. In Eastern Orthodox Christianity only two- 
dimensional images function as formal liturgical icons ${ }^{4}$.

Iconic images can be anthropomorphic and so represent a human form. Other iconic images depict animals, divine beings that combine human and nonhuman traits, or inanimate symbols such as a cross, a book, or a throne. The multiplication of images leads to issues of identity, as different forms are used to depict the same deity. Traditions with iconic images therefore develop an iconography, a detailed formal canon of distinguishing features of anatomy, color, clothing, ornamentation, and attributes held in the hands that allow the viewer to identify which deity or saint is depicted. The multiplication of images can also contribute to understandings of divinity as plural and diverse. Complex iconographies contribute to explicit polytheisms, with many deities, such as we find in the Hindu, Buddhist, Jain, Shinto, Daoist, Egyptian, and Greco-Roman traditions.

Images serve different functions in religious life. Some of them are visual symbols. They can be visual tools in the meditation of specially trained religious practitioners, who use two- or three-dimensional forms as props for visualization of deities. Images, especially two-dimensional ones with narrative themes, serve to educate people concerning essential religious truths or the history of a religious community. The Catholic pope Gregory the Great in the sixth century thus termed images "books of the illiterate." This equation of images with books is often found in elite criticisms of images as being suitable only for commoners or other more childlike and less-educated members of a religious community.

Images often appear on the outside of temples and shrines. Here they can serve as markers of sectarian identity. On the outside and inside of temples images can also serve an ornamental function, as they add to the grandeur of a building ${ }^{6}$.

${ }^{4}$ Some objects, such as Hindu, Buddhist, and Jain mandalas and yantras, are low-relief carvings and castings that at the same time share visual features with two-dimensional icons.

5 They also contribute to implicit polytheisms of minor deities or saints, such as we find in Catholic and Orthodox Christianity. In contrast, explicit monotheisms tend to employ a simplified iconography or be iconoclastic. Cf. Moshe BARASCH, Icon: Studies in the History of an Idea, New York, New York University Press, 1992, p. 132 sq.

${ }^{6}$ John E. CORT, “Images: images, icons, and...”, p. 4389. 


\subsection{Images as Divine presence}

Most of the religious rituals effect the transformation of the image from a humanly manufactured object into a receptacle or real presence of divinity. In Mesopotamia, for instance, the image is understood to have been produced by the cooperation of humans and gods. In many traditions there are stories of images that either were created by divine beings, or else were spontaneously material incarnations of the deity him- or herself.

This dual character of the image, as at once humanly created and a body for the divine, is reflected in various ways in the rituals. In the Mesopotamian ritual priests use a wooden sword symbolically to cut off the hands of the artisans, whereas the artisans themselves swear an oath that the image was made not by them but by their craft deities. In the Buddhist ritual in Sri Lanka the act of painting in the eye of the image to open it is considered so dangerous that no one can look at the image during this process, and even the craftsman who performs the act must do it with a mirror. This would appear to indicate a powerful presence in the image, greater than anything within normal human experience.

It is often not clear whether the image is a representation of a particular deity, or is the deity itself. The language of hymns and rituals, as well as stories concerning images, allow for both interpretations. Some paintings of images clearly depict an image in a temple. In others it is unclear if the painter has depicted the deity or an image of the deity.

A further ambiguity seen in consecration rituals is whether the image is the sole abode of a particular deity, or the abode of a deity who equally resides in other images. While the language and actions of the consecration ritual usually indicate that the image has now become a permanent abode of the divine, the language and actions of some daily rituals simultaneously indicate an understanding that the ritual practitioner invokes the deity into the image and then dismisses the deity at the conclusion of the ritual ${ }^{7}$.

In some traditions, such as the Mesopotamian, Egyptian, Hindu,

${ }^{7}$ Most images are the subject of annual or periodic rituals of purification and renewal. In some cases these rituals consist of a set of purifications; in others the image itself is repaired, reornamented, or even entirely refabricated. See: Yael BENTOR, Consecration of Images and Stūpas in Indo-Tibetan Tantric Buddhism, Leiden, E.J. Brill, 1996, p. 137. 
and Mahayana Buddhist, there is little or no theological problem caused by positing the presence of the deity, either in whole or as a partial incarnation, in the image. But other traditions deny this possibility. In Theravada Buddhism and Jainism the Buddha and the Jina, respectively, are understood no longer to be present in this world in a tangible sense. These traditions engage in more complicated explanations of what, if anything, is present in the image, and tie the presence to the intentions and actions of the Buddha or Jina several thousand years ago.

Christian theology also denies the possibility of real presence in an icon or image, reserving this (according to the Eastern Orthodox, Catholic, and some Protestant traditions) to the sanctified bread and wine in the Eucharist. A careful analysis of rituals and stories in traditions that theoretically deny presence, however, shows that many people act as if there were a divine presence in the image, so scholars must beware placing too much emphasis on theological arguments of absence.

\subsection{Ritual uses of images}

Consecrated images are the centers of interest of many rituals. Viewing an image is itself an efficacious ritual in many traditions, which leads to the elaborate ornamentation of images. In many cases, such as Hindu, Jain, and Christian images, the ornamentation is so extensive that it almost totally covers the image, so the image's identity is established more by the ornamentation than by the underlying "original" image. In Hinduism, Buddhism, and Jainism images are offered flowers, incense, lamps, edibles, and other physical substances. In Hindu Vaishnava traditions the deity is understood to consume the subtle essence of the offerings that are then returned to the person as prasada, literally "divine grace". In contrast, Jain and Hindu Shaiva traditions explicitly restrict such transactions. Hindu, Buddhist, and Jain rituals also involve the anointing of images with water, milk, and other liquids in a ritual idiom that shares much with the consecration of kings. In Christianity devotion to an image is usually expressed through kissing it and praying in front of it.

Rituals can differ according to the deity symbolized or embodied by the image. In Jainism, the eight-part ritual offering (Sanskrit astaprakart puja) is done only to images of the enlightened and liberated Jinas, whereas images of unliberated deities receive a different number of 
offerings $^{8}$. The Eastern Orthodox theologian Saint John of Damascus distinguished between veneration (Greek proskinesis, Latin dulia) directed toward a saint, and worship (Greek latreia, Latin latria), which is appropriate only toward Jesus as God. This distinction was adopted by Catholic theologians, who added an intermediate rite of special veneration (hyperdulia) in which the Virgin Mary was named the Mother of God'.

Image cults often involve processions, in which an important image is periodically taken out of the shrine and processed around the village or neighborhood ${ }^{10}$. Processions spread the power and blessings of the image throughout the geographical area encompassed by the procession. In traditions such as Hinduism before Indian independence, in which entry into many temples was prohibited to some lower castes, the procession also allows access to the image on the part of the total population.

Vows taken before an image may have the same binding significance as those taken before the deity or a religious leader. In the Jain tradition, for example, a person should be initiated into monkhood by another monk, but several twentieth-century Digambara monks initiated themselves in front of Jina images. Shingon Buddhist monks in medieval Japan also performed self-ordinations in front of Buddha images to start new monastic lineages. Buddhist monks in many traditions perform rites of confession in front of Buddha images ${ }^{11}$.

\subsection{Iconoclasm and justifications of images}

Traditions that devote extensive theological and ritual attention to images almost always generate countermovements in criticism or

${ }^{8}$ Diana L. Eck, Darshan: Seeing the Divine Image in India, 3rd ed., New York, 1998, p. 234.

${ }^{9}$ Leonid OuSPENSKY and Vladimir LossKy, The Meaning of Icons, Translated by G.E H. Palmer and E. Kadloubovsky. 2nd ed., New York, Crestwood, 1982.

${ }^{10}$ In some cases, it is the central image of a shrine that is processed. In others the main image remains permanently in the shrine, and a portable image stands in for it in the procession.

${ }^{11}$ Richard GOMBRICH, "The Consecration of the Buddhist Image", in Journal of Asian Studies, no. 26/1966, p. 29-30. 
opposition to images. The destruction of images (iconoclasm) is oftentimes accompanied by criticisms of other aspects of the material culture of the religion, of priestly hierarchies with special prerogatives and extensive powers, and of theological decentralizing through either polytheism or the development of cults of multiple subsidiary deities or saints.

In some cases, as in the critiques of the Arya Samaj in Hinduism, the Sthanakavasis and Terapanthis in Jainism ${ }^{12}$, and Lutherans in Christianity, iconoclasm is nonviolent and aims at convincing people to ignore and eventually reject images. In other cases, such as the Christian Iconoclastic Controversy of the eighth and ninth centuries and the Calvinist Reformation, the iconoclasm was more violent, with extensive destruction of images. Iconoclastic movements also lead to the development of selfconscious defenses of images and the cult of images. Saint John of Damascus and Saint Theodore of Studion articulated the Orthodox Christian theology of the image during the Iconoclastic Controversy; the Council of Trent confirmed the Catholic theology of images in response to the Protestant Reformation ${ }^{13}$. Iconoclastic opposition to images can also come from outside a tradition. It can be physically nonviolent, as in the case of the Christian polemics against Hindu idols in nineteenth- and twentiethcentury India, or it can result in the violent overthrow of images as witnessed most recently in 2001 by the destruction of the Buddha images at Baniyan in Afghanistan by the Taliban ${ }^{14}$.

$$
* *
$$

From the Christian theological standpoint, it is incumbent to us to affirm the significance and reality of the image cult. Thus, for Oriental Churches, the cult of icon uses fully the double power of transfer and of

${ }^{12}$ Caroline Humphrey and James LaidLaw, The Archetypal Actions of Ritual: A Theory of Ritual Illustrated by the Jain Rite of Worship, London, Oxford, 1994.

${ }^{13}$ Jaroslav PeliKAn, Imago Dei: The Byzantine Apologia for Icons, Princeton, N.J., 1990, p. 156 sq.

${ }^{14}$ John E. CoRT, "Images: images, icons, and...", p. 4392. One of the widely reported iconoclastic violence was the destruction of the two 125-foot-high statues of Buddha in Afghanistan, in early March 2001 through the orders of Mullah Muhammad Omar, the leader of the Taliban, who described the statues as idols insulting to Islam. Despite pleas from international quarters, many of which regarded the statues, which have been standing for about 1,500 years, as archaeological monuments of significant cultural history, the Taliban used mortars and canons to destroy them. 
supernatural epiphany of the symbol. Only the Orthodox Church, totally applying the decisions of the Seventh Ecumenical Council, that prescribes the veneration of icons, gives to image the full sacramental role of "double servitude" which makes through the image, i.e. of the significant, the relationship between signified and adoring conscience "not to be purely conventional, but radically intimate"15.

As the renowned French orthodox theologian Olivier Clément points out: "Christ is not only the Word of God, but also His image. The Incarnation underlain the icon and the icon proves the incarnation. Divine grace dwells in the icon."16 This intermediate role played by the icon is symbolized by the iconostasis itself, which in its center always represents the Deisis (the Intercession) figurate by the Virgin and Saint John.

Iconoclasm, in its turn, as the art historian David Morgan argued, may not always be the destruction of images but rather a strategy of replacement, simply because none of the monotheistic world religions has ever operated without images ${ }^{17}$. Iconoclasm reached its zenith in the encounter of Christianity with other cultures and religions. Christian missionaries in many lands attached religious significance to images and encouraged new converts to Christianity to either abandon these images or destroy them. In the twenty-first century, radical Evangelical Christian groups in many parts of the world have continued this iconoclastic tradition as a conversion strategy. For example, in 2003 the Warriors of David, a dissident Baptist group (based in southern Chile), burned a statue of the Roman Catholic Virgin of Carmen, claiming that the statue was an idol and that therefore the festival associated with it was a pagan event.

But it is difficult to find a single criterion that can be used to judge an image as idolatrous because there are so many varieties of images and so many varieties of devotion. For example, while Protestant reformers

15 B. Morel, Le signe sacre, Paris, Flammarion, 1959, p. 195 sq., apud Gilbert DurAND, Aventurile imaginii. Imaginaţia simbolică. Imaginarul (Adventures of the image. Symbolic imagination. The imaginary), Romanian translation by Muguraş Constantinescu and Anişoara Bobocea, București, Neemira, 1999, p. 39.

${ }^{16}$ Apud Gilbert Durand, Aventurile imaginii..., p. 40.

${ }^{17}$ Indeed, the polemics against images are associated with the history of Christian inner rejuvenation, the promotion of a sectarian faith, and the sustenance of evangelical revival. Cf. David MoRGAN, “The vicissitudes of seeing: Iconoclasm and idolatry”, in Religion, no. 33/2003, p. 171. 
discarded and destroyed images during the Reformation and Catholics viewed such destructions as abominable, both claimed to practice the true Christian religion ${ }^{18}$.

It is doubtful whether iconoclasm ever succeeded in eliminating any nonliterate religion or any genre of art altogether; rather, it has succeeded only in limiting the power of images, by depriving them of their economic advantage and privatizing the worship associated with them. Overall, iconoclasm is a complex social phenomenon. It can be described as vandalism, as an aspect of social conflict, as a process of refinement of art (when the objects destroyed are accorded less significance), as the promotion of rationality, or as the strengthening of religious bigotry ${ }^{19}$.

On the whole, what has to be stressed out is the point that before the Renaissance and Reformation, holy images were treated not as "art" but as objects of veneration which possessed the tangible presence of the Holy, as the German art historian Hans Belting proves it, tracing the long history of the sacred image and its changing role in European culture $^{20}$. Art, as it is studied by the discipline of Art History today, existed in the Middle Ages no less than it did afterwards. After this period, however, art took on a different meaning and became acknowledged for its own sake-art as invented by a famous artist and defined by a proper theory. While the images from olden times were destroyed by iconoclasts in the Reformation period, images of a new kind began to fill the art collections which were just then being formed. The era of art, which is rooted in these events, lasts until this present day. From the very beginning, it has been characterized by a particular kind of historiography which, although called the history of art, in fact deals with the history of $\operatorname{artists}^{21}$.

18 Matthews A. OJo, "Idolatry", in Daniel A. Stout (ed.), Encyclopedia of Religion, Communication, and Media, New York, London, Routledge, 2006, p. 171.

${ }^{19}$ Ibidem, p. 171.

${ }^{20}$ Hans Belting, Likeness and Presence: A History of the Image before the Era of Art, translated by Edmund Jephcott, Chicago and London, University of Chicago Press, 1994. His masterpiece Likeness and Presence looks at the beliefs, superstitions, hopes, and fears that come into play as people handle and respond to sacred images, and presents a compelling interpretation of the place of the image in Western history.

${ }^{21}$ Hans Belting, in Foreword at Likeness and Presence, p. xxi. 


\section{Transformations of the Image in postmodernity}

Modernity entered history as a progressive force promising to liberate humankind from ignorance and irrationality ${ }^{22}$, but one can readily wonder whether that promise has been sustained. As we entered the twenty-first century, the "modern" record - world wars, the rise of Nazism, concentration camps (in both East and West), genocide, worldwide depression, Hiroshima, Vietnam, Cambodia, the Persian Gulf, and lately the huge migration from Syria and some other oriental countries, the widening gap between rich and poor - makes any belief in the idea of progress or faith in the future seem questionable. Postmodernists criticize all that modernity has engendered: the accumulated experience of Western civilization, industrialization, urbanization, advanced technology, the nation state, life in the "fast lane".

Some consider postmodernism simply a reaction to modernism and to Enlightenment, especially; others believe that it represents an advanced modernism, etc. According to Andreas Huyssen, postmodernism "is part of a cultural transformation that is emerging slowly but surely in Western societies, a change in sensitivity, for whom the term postmodernism is, for the time being, fully fit" ${ }^{\prime 2}$. Gene E. Veith, in turn, synthesizes the features of postmodern phenomenon as such: social constructivism, cultural determinism, rejection of individual identity, refusal of humanism, denial of the transcendent, rejection of reason, revolutionary critique of the existing order ${ }^{24}$.

Postmodernism abandons modernism, embodied by humanistic philosophy of the European Enlightenment, emerged with the idea of René Descartes, of the autonomous man, i.e. one who starts from his own

${ }^{22}$ Some maintain that the modern age ranged from the fifteenth to the nineteenth centuries and that postmodernism has been evolving for the last 150 years. Others contend that post-modernity originated in the late 1960s and early 1970s. Cf. Pauline Marie Rosenau, Post-modernism and the social sciences. Insights, inroads, and intrusions, New Jersey, Princeton University Press, 1992, p. 20.

${ }^{23}$ In Jeffrey C. Alexander and Steven SeIDman (eds.), Cultură şi societate. Dezbateri contemporane (Culture and society. Contemporary debates), Romanian transl. by Simona Lebădă, Mihaela Sadovschi and Liliana Scărlătescu, Iaşi, Institutul European, 2001, p. 329.

24 Gene Edward Veith Jr., Postmodern Times: A Christian Guide to Contemporary Thought and Culture Illinois: Crossway Books, Wheaton, 1994, p. 15 ff. 
thoughts (the famous saying "I think, therefore I am"), excluding any necessity of God or revelation ${ }^{25}$.

The adepts of postmodernism affirm that modern rationalism and technological proliferation brought us to the brink of disaster. The myth of "modern progress" ends up in a nightmare of violence, both for those it marginalizes, and for the whole earth, as well. Therefore, we see nowadays so many people who show a special interest in primitive cultures and in those views on life and world that promote unity between humanity and nature and which no longer consider humanity more important than nature ${ }^{26}$.

Postmodernist creeds and mentality have long penetrated the mass media and the level of mass culture. Commercial televisions have taken on the way of postmodernist thinking by promoting it with obstinacy, which makes almost impossible, given the importance of the image in the world we live in, the counteraction of the postmodernist mentality ${ }^{27}$.

In such new conditions of communication, and of the new paradigm of thinking, the sacredness of the image, consequently, has passed through many avatars ${ }^{28}$. Contemporary civilization, regarded as marking the end of "Gutenberg Galaxy"29 enjoys the ubiquity of images

25 Cf. Alexandru-Corneliu ARION, "Human depersonalization as a symptom of postmodern society", in International Journal of Orthodox Theology (IJOT), no. 5:1/2014, p. 42.

${ }^{26}$ See, inter alia: Jim LEFFEL and Dennis MCCALLUM, "Postmodern Impact: Religion", in Dennis McCallum, The Death of Truth: What's Wrong with Multiculturalism, the Rejection of Reason and the New Postmodern Diversity, Minneapolis, Bethany House Publishers, 1996, p. 200-214.

27 The postmodern society is "the television society", as Jean Baudrillard, the postmodernist sociologist said. Television unarguably and authoritatively controls people's thoughts and behaviors to a considerable extent. Apud Vasile BoARI, Postmodernism şi Creştinism (Postmodernism and Christianity). V. https://www.scribd.com/document/38027183/Boari-Crestinism-si-Postmodernism

28 Among those imposed by the postmodernity are: the denial of metaphysics and radicalization of hermeneutics, as science of interpretation; deconstructivism, viz. all that was built by man (or God) can be deconstructed; there is no objective truth, because what we call objective truth is merely fiction; there is no absolutes, everything is relative, in all levels, from knowledge to moral and culture. Cf. Alexandru-Corneliu ARION, "Human depersonalization...", p. $40 \mathrm{ff}$.

29 Marshall McLuhan, Mass-media sau mediul invizibil (Media or the invisible environment), Romanian translation by Mihai Moroiu, Bucureşti, Nemira, 1997, p. 
of the universe, manufactured, distributed and reproduced through a variety of means, and covering a very broad spectrum of human activities $^{30}$.

Among the new concepts emerged for the last few decades is that of hyperreality which is closely related to that of the simulacrum: a copy or image without reference to an original. In postmodernism, hyperreality is the result of the technological mediation of experience, where what passes for reality is a network of images and signs without an external referent, such that what is represented is representation itself. The postmodernist sociologist Jean Baudrillard argues that all of these realities have become simulations, that is, signs without any referent, because the real and the imaginary have been absorbed into the symbolic. He presents hyperreality as the terminal stage of simulation, where a sign or image has no relation to any reality whatsoever, but is "its own pure simulacrum"31 The real, he argues, has become an operational effect of symbolic processes, just as images are technologically generated and coded before we actually perceive them ${ }^{32}$.

Postmodern conceptions of art are more invested in art's relational potential, its performativity, than in its iconography. Thus the bond between a theological interpretation of images based on traditional religious content and an account of art's powers has more than an incidental common ground in relationality. We can learn something from painting, not as a transparent medium of representation but as alternative semiotic production ${ }^{33}$.

Our contact with Representation has become the main source of knowledge and guidance in the world. Objective, human or abstract

109.

${ }^{30}$ Raluca SOARE, "Variaţii ontologice în statutul imaginii" (Ontological variations in the status of the image), in Transilvania, no. 2/2007, p. 93.

${ }^{31}$ Jean BAUdRILlARD, Simulacra and Simulation, Sheila Faria Glaser (trans.), Ann Arbor, University of Michigan Press, 1994, p. 6.

32 "Postmodernism", in Edward N. ZaLTA (ed.), Stanford Encyclopedia of Philosophy, substantive revision Thuersday February 5th, 2015. https://plato.stanford.edu/entries/postmodernism (accessed April 29, 2017).

33 Mieke BAL, "Postmodern Theology as Cultural Analysis", in Graham Ward (ed.), The Blackwell Companion to Postmodern Theology, Oxford, Blackwell Publishing Ltd, 2005 , p. 9. 
realities are rebuilt or staged by articulating three plans: narrative, figurative, and conceptual. But any image goes beyond these plans, being not only a representation ${ }^{34}$, but also a presentification, in the sense that any image has the power to go beyond mere figurative and representative quality in order to manifest its essential function: to take away the appearance of what is not.

Image has slipped from ambition to have access to a reality that must not in so much represent it as to manifest it, to the ambition to seize the reality by promoting a system of signs that functions virtually empty and that refers to nothing else but to itself, that is to a logic of nonsense ${ }^{35}$. The excess of external image can cause the damage to human interiority imaginative and of symbolic heritage of Anthropos universalis.

Instead of conclusion, we appeal to two sayings of great scholars separated by almost one century: "Tradition without modernity is a dead end, modernity without tradition is an irremediable and utter insanity" (George Edward Saintsbury); and: "The world is good by purpose, beautiful as creation, complex through living and spiritual through materiality" (Horia Bernea). Unfortunately, today's humanity seems to be nothing more than an enormous mouth that emphatically and endlessly pronounces the name of Man.

\section{References:}

1. AleXAnder, Jeffrey C. / SeIDman, Steven (eds.), Cultură şi societate. Dezbateri contemporane (Culture and society. Contemporary debates), Romanian transl. by Simona Lebădă, Mihaela Sadovschi and Liliana Scărlătescu, Iaşi, Institutul European, 2001.

2. ARION, Alexandru-Corneliu, "Human depersonalization as a symptom of postmodern society", in International Journal of Orthodox Theology (IJOT), no. 5:1/2014.

3. BAL, Mieke, "Postmodern Theology as Cultural Analysis", in Graham Ward (ed.), The Blackwell Companion to Postmodern Theology,

${ }^{34}$ L. Martin, Le Portrait du Roi, Paris, Minuit, 1981, p. 9. V. Raluca SoARE, "Variaţii ontologice în statutul imaginii", p. 93.

35 F. Laplantine, La Culture du Psy, Privat, 1975, p. 21 apud Jean-Jacques WunENBURGER, Viaţa imaginilor (Life of images), Romanian transl. by Ionel Buşe, Cluj, Cartimpex, 1998, p. 179. 
Oxford, Blackwell Publishing Ltd, 2005.

4. BARASCH, Moshe, Icon: Studies in the History of an Idea, New York, New York University Press, 1992.

5. BAUdRILlard, Jean, Simulacra and Simulation, Sheila Faria Glaser (trans.), Ann Arbor: University of Michigan Press, 1994.

6. Belting, Hans, Likeness and Presence: A History of the Image before the Era of Art, translated by Edmund Jephcott, Chicago and London, University of Chicago Press, 1994.

7. Bentor, Yael, Consecration of Images and Stüpas in Indo-Tibetan Tantric Buddhism, Leiden, E.J. Brill, 1996.

8. CORT, John E., "Images: images, icons, and idols", in Encyclopedia of Religion, Vol. 7.

9. DAVIS, Richard H., "Images: veneration of images", in Lindsay JONES (editor in chief), Encyclopedia of Religion, Vol. 7: Iconography - Justin Martyr, Macmillan Reference USA, Thomson Gale, 2005.

10. DURAND, Gilbert, Aventurile imaginii. Imaginaţia simbolică. Imaginarul (Adventures of the image. Symbolic imagination. The imaginary), Romanian translation by Muguraş Constantinescu and Anişoara Bobocea, București, Neemira, 1999.

11. ECK, Diana L., Darshan: Seeing the Divine Image in India, 3rd ed., New York, 1998.

12. GOMBRICH, Richard, "The Consecration of the Buddhist Image", in Journal of Asian Studies, no. 26/1966.

13. Humphrey, Caroline / LaIDlaw, James, The Archetypal Actions of Ritual: A Theory of Ritual Illustrated by the Jain Rite of Worship, London, Oxford, 1994.

14. LEFFEL, Jim / MCCALLUM, Dennis, "Postmodern Impact: Religion", in Dennis McCallum, The Death of Truth: What's Wrong with Multiculturalism, the Rejection of Reason and the New Postmodern Diversity, Minneapolis: Bethany House Publishers, 1996.

15. MCLuHAN, Marshall, Mass-media sau mediul invizibil (Media or the invisible environment), Romanian translation by Mihai Moroiu Bucureşti, Nemira, 1997.

16. MORGAN, David, "The vicissitudes of seeing: Iconoclasm and idolatry", in Religion, no. 33/2003.

17. OJo, Matthews A., "Idolatry", in Daniel A. Stout (ed.), Encyclopedia of Religion, Communication, and Media, New York, London, Routledge, 2006.

18. OUSPENSKY, Leonid / LOSSKY, Vladimir, The Meaning of Icons, translated by G.E H. Palmer and E. Kadloubovsky, 2nd ed., New York, 
Crestwood, 1982.

19. PeliKan, Jaroslav, Imago Dei: The Byzantine Apologia for Icons, Princeton, N.J., 1990.

20. Rosenau, Pauline Marie, Post-modernism and the social sciences. Insights, inroads, and intrusions, New Jersey, Princeton University Press, 1992.

21. SOARE, Raluca, "Variaţii ontologice în statutul imaginii" (Ontological variations in the status of the image), in Transilvania, no. 2/2007.

22. VeITH Jr., Gene Edward, Postmodern Times: A Christian Guide to Contemporary Thought and Culture, Illinois, Crossway Books, Wheaton, 1994.

23. WunENBURGER, Jean-Jacques, Filozofia imaginii (The philosophy of the image), edited and Afterword by Sorin Alexandrescu, Romanian transl. by Muguraş Constantinescu, Iaşi, Polirom, 2004.

24. WunENBURGER, Jean-Jacques, Viaţa imaginilor (Life of images), Romanian transl. by Ionel Buşe, Cluj, Cartimpex, 1998.

\section{Web sources:}

25. BOARI, Vasile, Postmodernism şi Creştinism (Postmodernism and Christianity). https://www.scribd.com/document/38027183/BoariCrestinism-si-Postmodernism (accessed April 27, 2017).

26. Zalta, Edward N. (ed.), Stanford Encyclopedia of Philosophy, substantive revision Thuersday February 5th, 2015. https://plato.stanford.edu/entries/postmodernism (accessed April 29, 2017). 